\title{
PENERAPAN METODE FUZZY TSUKAMOTO UNTUK MEMPREDIKSI ANGKA PRODUKSI RENDANG PADA TOKO RENDANG ASESE PADANG BERBASIS PHP MySQL
}

\author{
Wanda Ilham \\ Sekolah Tinggi Manajemen Informatika dan Komputer CIC Cirebon \\ Jln. Kesambi 202, Kota Cirebon, Jawa Barat. Telp.(0231) 220250 \\ Wanda.ilham1993@gmail.com
}

\begin{abstract}
Keuntungan yang maksimal diperoleh dari penjualan yang maksimal. Penjualan yang maksimal yaitu yang dapat memenuhi permintaan-permintaan yang ada. Adanya penentuan jumlah produksi yang direncanakan untuk memenuhi tingkat produksi guna memenuhi tingkat penjualan yang direncanakan atau tingkat permintaan pasar. Faktor-faktor yang perlu diperhatikan dalam menentukan jumlah produksi, antara lain: jumlah persediaan dan jumlah permintaan. Jumlah permintaan dan persediaan merupakan suatu ketidakpastian. Logika fuzzy merupakan salah satu ilmu yang dapat menganalisa ketidakpastian. Salah satu metode aturan fuzzy adalah Tsukamoto, yaitu metode yang sering digunakan untuk membangun sebuah sistem yang penalarannya menyerupai instuisi atau perasaan manusia. Proses perhitungannya cukup kompleks sehingga membutuhkan waktu relatif lama, tetapi metode ini memberikan hasil dengan nilai ketelitian yang tinggi. Toko Rendang Asese merupakan suatu perusahaan yang melakukan produksi rendang dalam jumlah besar setiap harinya. Oleh karena itu, perencanaan jumlah produksi rendang Toko Rendang Asese sangatlah penting. Agar dapat memenuhi permintaan pasar dengan tepat dan dengan jumlah yang sesuai. Dengan menggunakan aplikasi ini diharapkan dapat memberikan kemudahan bagi pihak perusahaan untuk memprediksi jumlah produksi berdasarkan jumlah permintaan dan data persediaan yang ada, agar dapat mencapai produksi yang optimal.
\end{abstract}

Kata kunci: Fuzzy,logika fuzzy,tsukamoto,rendang,produksi

\begin{abstract}
Abstrak
Maximum profit is obtained from maximum sales. Maximum sales are those that can meet existing requests. The determination of the amount of production planned to meet the level of production in order to meet the planned level of sales or the level of market demand. Factors that need to be considered in determining the amount of production, among others: the amount of inventory and the number of requests. The amount of demand and supply is an uncertainty. Fuzzy logic is one of the sciences that can analyze uncertainty. One method of fuzzy rule is Tsukamoto, a method that is often used to build a system whose reasoning resembles human instincts. The calculation process is quite complex so it requires a relatively long time, but this method produces results with high accuracy. Rendang Asese is a company that produces large quantities of rendang every day. Therefore, the planning of the amount of rendang production from the Rendang Asese Shop is very important. In order to be able to meet market demand appropriately and with the appropriate amount. By using this application it is expected to provide convenience for the company to predict the amount of production based on the number of requests and existing inventory data, in order to achieve optimal production.
\end{abstract}

Keywords: Fuzzy, fuzzy logic, tsukamoto, rendang, production

\section{Pendahuluan}

Rendang adalah makanan yang biasa di kosumsi oleh masyarakat indonesia. Rendang mengandung energi sebesar 193 kilokalori, protein 22,6 gram, karbohidrat 7,8 gram, lemak 7,9 gram, 
kalsium 474 miligram, fosfor 211 miligram dan zat besi 14.9 miligram. Selain itu di dalam Rendang juga terkandung vitamin A sebanyak 69 IU, vitamin B1 0.12 miligram Hasil tersebut didapat dari melakukan penelitian terhadap 100 gram Rendang, dengan jumlah yang didapat dimakan sebanyak 100\%

Pada masa kini peluang bisnis dibidang makanan cukuplah menjanjikan dikarenakan sifat instant yang dimiliki produk berkemasan tersebut. Dengan kondisi tersebut pemanfaatan peluang bisnis makanan Rendang berkemasan sangat cocok untuk penjualan demi mendapatkan keuntungan yang besar, serta mampu menunjang kebutuhan gizi dengan efisiensi makanan Rendang ini. Oleh karena itu Toko Rendang Asese mengolah makanan yang mudah dibawa dan berkemasan ini.

Untuk itu diperlukan sebuah metode untuk mengatasi masalah tersebut. Sehingga dengan adanya permasalahan tersebut diperlukan suatu sistem yang dapat mempermudah untuk mengantisipasi ketidakstabilan proses penentuan angka produksi berdasarkan data persediaan dan data permintaan produksi Makalah harus berisi Latar Belakang, pernyataan, Rasional.

\subsection{Rumusan Masalah}

Penulis merumuskan masalah sebagai berikut :

1. Bagaimana membangun sistem yang mampu di aplikasikan secara efektif dan efisien?

2. Bagaimana metode Fuzzy logic dapat membantu pihak perusahaan dalam menentukan keputusan

\subsection{Batasan Masalah} yang tepat untuk penentuan hasil produksi ? berikut :

Adapun batasan - batasan masalah dalam penelitian ini, penulis membatasi masalah sebagai

1. Perancangan aplikasi ditunjukkan untuk memprediksi angka produksi pada Toko Rendang Asese berdasarkan data angka permintaan, data persediaan dan data produksi dari hari/bulan sebelumnnya.

2. Penalaran fuzzy menggunakan metode Tsukamoto.

3. Aplikasi dirancang berbasis web dengan bahasa pemrograman PHP.

\subsection{Hipotesa}

Berdasarkan perumusan masalah, maka dapat dikemukakan suatu hipotesa, yaitu diharapkan :

1. Dengan menggunakan aplikasi Fuzzy Logic dengan metode Tsukamoto dapat menstabilkan produksi rendang pada Toko Rendang Asese.

2. Aplikasi Fuzzy Logic menggunakan metode Tsukamoto mudah dimengerti.

3. Dengan penerapan aplikasi Fuzzy Logic berbasis web dapat diakses user dengan mudah asal terkoneksi dengan internet.

\subsection{Tujuan Penelitian}

Tujuan penelitian yang dilakukan penulis adalah untuk :

1. Untuk menstabilkan jumlah produksi dan penjualan dengan menggunakan aplikasi Fuzzy Logic dengan metode Tsukamoto.

2. Untuk dapat merencanakan jumlah produksi dan menentukan biaya produksi yang minimal.

3. Untuk dapat menghasilkan informasi yang tepat dan berguna bagi perusahaan.

4. Menerapkan perkembangan teknologi informasi pada Toko Rendang Asese untuk menstabilkan aktifitas produksi.

\subsection{Manfaat Penelitian}

Adapun Manfaat penelitian yang dapat diperoleh adalah sebagai berikut :

1. Menambah wawasan dan kemampuan dalam mengaplikasikan ilmu -ilmu teknik berdagang, khususnya dalam bidang perencanaan produksi untuk memaksimalkan keuntungan toko.

2. Mengetahui faktor - faktor yang mempengaruhi dalam penentuan jumlah produksi. 
3. Memberikan informasi kepada pihak toko dalam menetukan jumlah produksi agar dapat mengatasi fluktuasi permintaan konsumen dengan biaya produksi yang minimal.

4. Dapat digunakan sebagai bahan pertimbangan bagi pihak toko dalam melakukan perencanaan jumlah pada periode yang akan datang.

\section{Kajian Pustaka}

\subsection{Fuzzy Logic}

Suatu cabang ilmu Artificial Inteligence, yaitu sutau pengetahuan yang membuat computer dapat meniru kecerdasan manusia sehingga diharapkan komuter dapat melakukan hal hal yang apabila dikerjakan manusia memerlkan kecerdasan buatan. Dengan kata lain fuzzy logic mempunyai fungsi untuk "meniru" kecerdasan yang dimiliki manusia untuk melakukan sesuatu dan mengimplementasikannya kesuatu perangkat, missal robot, kendaraan, peralatan rumah tangga, dan lain-lain

\subsection{Inference}

Melakukan penalaran menggunakan fuzzy input dan fuzzy rules yang telah ditentukan sehingga menghasilkan fuzzy output. Terdapat tiga metode fuzzy yang digunakan secara luas dalam berbagai aplikasi, yaitu: metode mamdani, metode sugeno dan metode tsukamoto. Secara garis besar metode Mamdani dalam penggunaannya lebih humanis lebih cocok masukkan yang diterima oleh manusia daripada mesin, mudah diterima penalaranya tetapi tidak terdapat kontrol pada metode Mamdani.Pada metode Tsukamoto, setiap konsekuen pada aturan yang berbentuk IF THEN harus direpresentasikan dengan suatu himpunan fuzzy dengan fungsi keanggotaan monoton. Sebagai hasilnya, keluaran hasil inferensi dari tiaptiap aturan diberikan secara tegas (crisp) berdasarkan $\alpha$-predikat (fire strength).

Hasil akhir menggunakan rata-rata terbobot. Bentuk model fuzzy Tsukamoto adalah :

$\mathrm{IF}(\mathrm{X}$ is $\mathrm{A})$ and $(\mathrm{Y}$ is $\mathrm{B})$ THEN $(\mathrm{Z}$ is $\mathrm{C})$

Beberapa aturan dapat dibentuk untuk mendapatkan nilai $\mathrm{z}$ akhir. Misalkan ada dua aturan yang digunakan yaitu :

$\mathrm{IF}(\mathrm{X}$ is $\mathrm{A} 1)$ AND ( $\mathrm{Y}$ is $\mathrm{B} 1)$ THEN ( $\mathrm{Z}$ is $\mathrm{C} 1)$

$\operatorname{IF}(\mathrm{X}$ is $\mathrm{A} 2)$ AND ( $\mathrm{Y}$ is B2) THEN ( $\mathrm{Z}$ is $\mathrm{C} 2$ )

Dalam inferensinya, metode tsukamoto menggunakan tahapan berikut

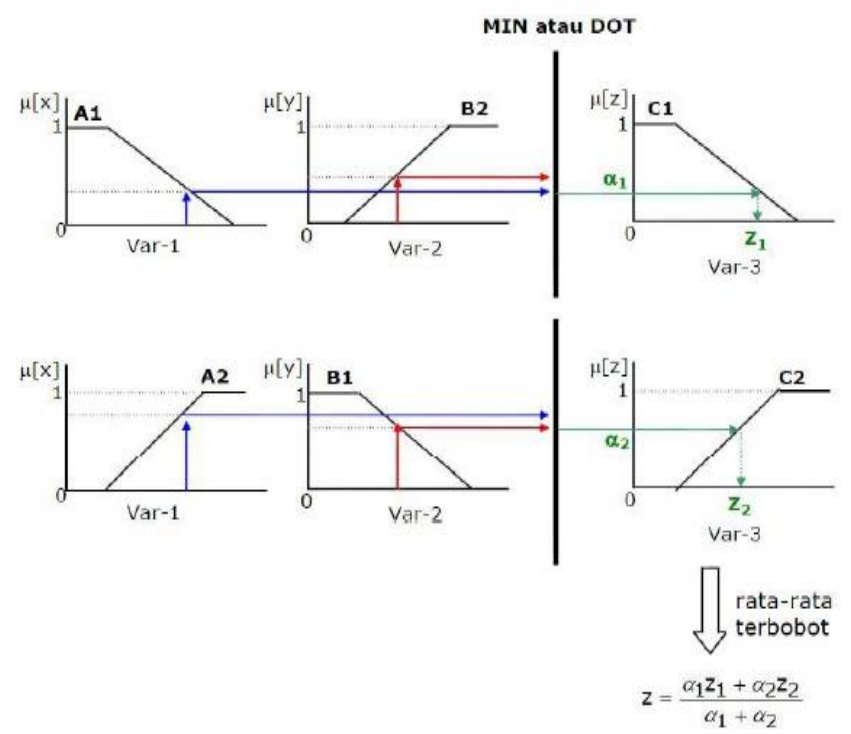

Gambar 1 Proses Inferensi Metode Tsukamoto 


\section{Metodologi}

\subsection{Pembentukan Rule}

Rule merupakan serangkaian aturan sebagai dasar perhitungan yang akan dilakukan, aturan-aturan yang relevan didapat dari history aktivitas produksi pada Rendang Asese.

Adapun aturan-aturan yang terbentuk dari kasus produksi pada Rendang Asese dideklarasikan dalam bentuk tabel seperti berikut

Tabel 1. Pembentukan Rule

\begin{tabular}{|l|l|l|l|}
\hline Rule ke- & $\begin{array}{l}\text { Himpunan } \\
\text { Permintaan }\end{array} \quad$ Fuzzy & $\begin{array}{l}\text { Himpunan } \\
\text { Persediaan }\end{array} \quad$ Fuzzy & $\begin{array}{l}\text { Himpunan } \\
\text { Produksi }\end{array} \quad$ Fuzzy \\
\hline 1 & Turun & Sedikit & Berkurang \\
\hline 2 & Turun & Banyak & Berkurang \\
\hline 3 & Naik & Sedikit & Bertambah \\
\hline 4 & Naik & Banyak & Bertambah \\
\hline
\end{tabular}

\subsection{Tahapan Penelitian}

\section{Melakukan Penelitian Pendahuluan}

Penelitian pendahuluan ini yang harus dilakukan adalah dengan menentukan objek yang akan diteliti serta memahami objek secara keseluruhan, dan mengidentifikasi masalah-masalah yang ada dalam objek penelitian tersebut. Kemudian peneliti membuatnya dalam suatu rumusan masalah yang nantinya akan dicari sutu solusi yang tepat untuk mengatasi permasalahan-perrmasalahan yang ada pada objek yang diteliti.

\section{Melakukan Pengumpulan Data}

Dalam melakukan pengumpulan data pada objek yang akan dilakukan penelitian oleh penulis membutuhkan data dan referensi dari berbagai sumber. Sumber tersebut berupa buku,jurnal,e-book yang berhubungan dengan penelitian ini

\subsection{Melakukan Analisa}

\section{a.Analisa Data}

Analisa data merupakan tahap yang paling penting dalam pengembangan sebuah sistem, pengolahan data dan pengkajian serta identifikasi masalah yang nantinya akan ditemukan solusi dalam menyelesaikan permasalahan-permasalahan yang ada

\section{b.Analisa Sistem}

Analisa sistem dilakukan untuk mengetahui dan mengembangkan sistem yang sedangberjalan baik yang berupa hambatan-hambatan yang terjadi, kekurangan-kekurangan nyadan lain-lain sebagaiman tujuan yang ingin dicapai yaitu untuk mengoptimalkan dalam pengimplementasiannya.

c. Melakukan Perancangan

Dalam melakukan perancangan sistem, penulis menggunakan UML sebagai alat bantu untuk menggambarkan alur kerja dari sistem yang akan dirancang nantinya, dengan menggunakan diagram-diagram dari UML, diantaranya sebagai berikut :

\section{Usecase Diagram}


2. Class Diagram

3. Statechart Diagram

4. Activity diagram

5. Sequence Diagram

6. Colaboration Diagram

7. Deployment Digram

\subsection{Perancangan Sistem Dengan Menggunakan UML}

Perancangan aplikasi Fuzzy Logic ini dirancang menggunakan alat bantu berupa UML (Unified Modelling Language) agar mempermudah memindahkan konsep sistem yang dirancang ke dalam bentuk program, dimana perancangannya digambarkan dalam bentuk diagram-diagram. Adapun dalam perancangan aplikasi ini penulis menggunakan 7 (tujuh) diagram UML diantaranya sebagai berikut :

\section{Use Case Diagram}

Use Case diagram menggambarkan bagaimana proses-proses yang dilakukan oleh aktor terhadap sebuah sistem. Ada 1 aktor yang terlibat dalam aplikasi Fuzzy logic ini yaitu admin.

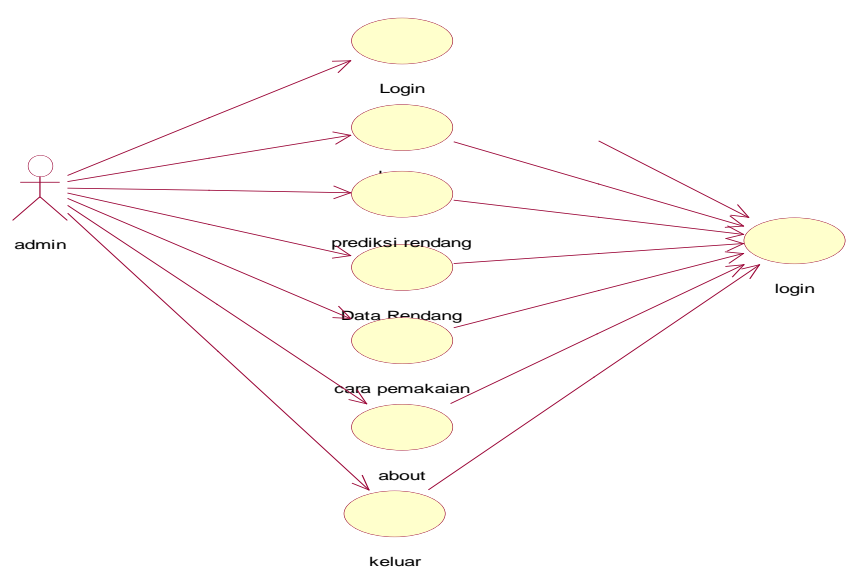

Gambar 2. Use Case Diagram

\section{Class Diagram}

Diagram kelas atau class diagram menggambarkan struktur sistem dari segi pendefenisian kelaskelas yang akan dibuat untuk membangun sistem. Kelas memiliki apa yang disebut atribut dan mode operasi.

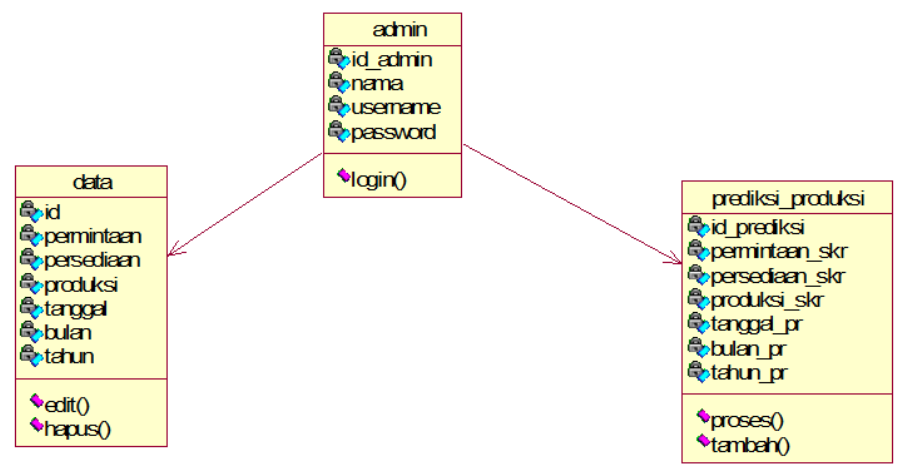

Gambar 3. Class Diagram 


\section{Sequence Diagram}

Diagram sekuen menggambarkan kelakuan objek pada use case dengan mendeskripsikan waktu hidup objek dan message yang dikirmkan dan diterima antar objek.

Banyaknya diagram sekuen yang harus digambarkan adalah minimal sebanyak pendefenisian use case yang memiliki proses sendiri atau yang penting semua use case yang telah didefinisikan interaksi jalannya pesan sudah dicakup pada diagram sequence.

\section{a) Sequence Diagram Home Admin}

Sequence diagram tampilkan home admin mendeklarasikan admin yang telah login dan sistem akan menampilkan halaman utama sistem. Adapun alur kerja dan interaksi disaat tampilkan home dijalankan tampak seperti gambar berikut :

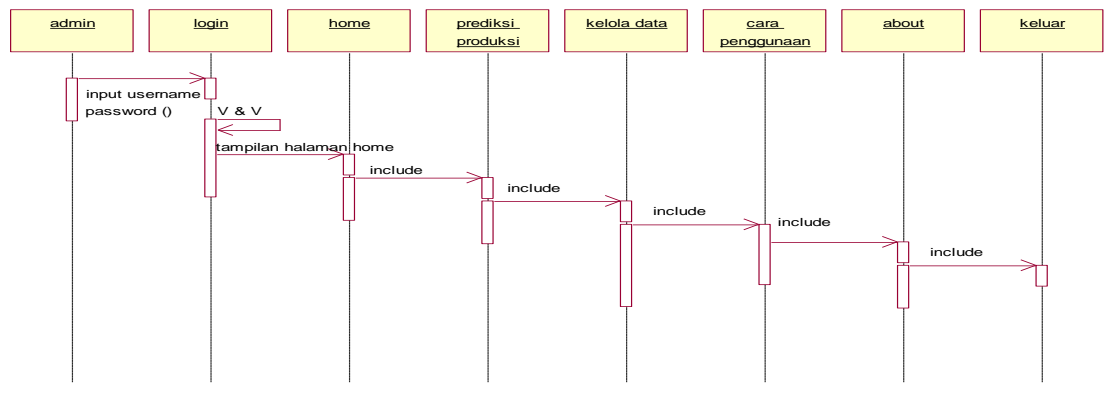

\section{Gambar 4. Sequence Diagram Home Admin}

b) Sequence Diagram Kelola Data

Sequence diagram kelola data mendeklarasikan alur kerja dan interaksi timbal balik antara admin dan sistem serta database dalam menampilkan data laporan produksi perusahaan dan juga menampilkan fungsi edit dan hapus

Adapun alur kerja dan interaksi saat admin melakukan aksi laporan produksi tampak seperti gambar berikut:

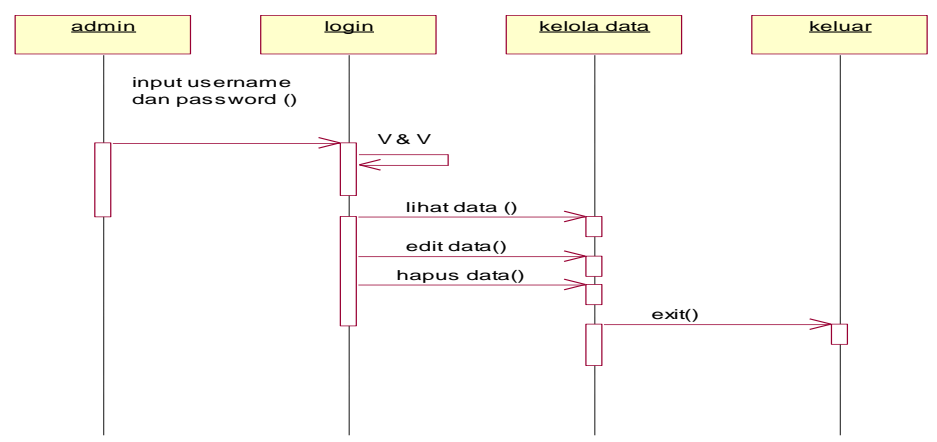

Gambar 5. Sequence Diagram Kelola Data

c) Sequence Diagram Prediksi Produksi

Sequence diagram Prediksi Produksi mendeklarasikan alur kerja dan interaksi timbal balik antara admin dan sistem serta database dalam melakukan prediksi jumlah produksi dengan perhitungan fuzzy logic tsukamoto.

Penerapan Metode Fuzzy Tsukamoto untuk memprediksi angka produksi rendang pada Toko rendang Asese Padang Berbasis PHP dan My sql-(Wanda Ilham) 
Adapun alur kerja dan interaksi saat admin melakukan aksi prediksi produksi tampak seperti gambar berikut :

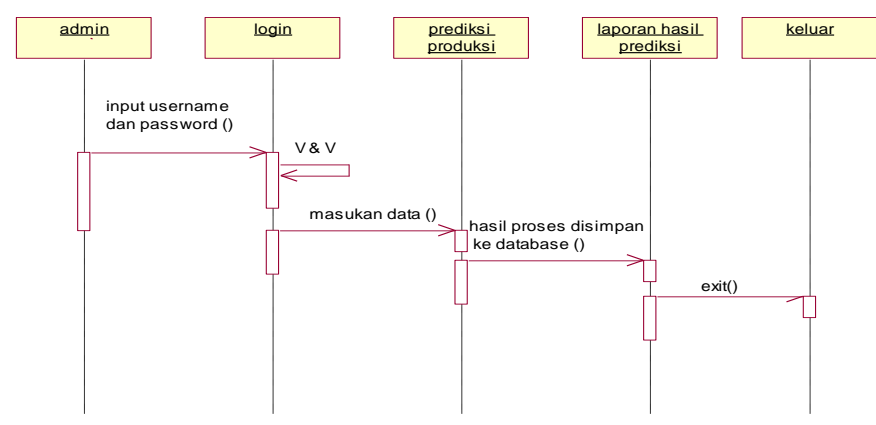

\section{Gambar 6. Sequence Diagram Prediksi Produksi}

\section{Collaboration Diagram}

Collaboration diagram adalah cara alternatif untuk mengetahui tahap-tahap terjadinya suatu aktivitas dan menunjukkan physical view dari suatu sistem yang akan dibangun. Collaboration diagram menekankan pada urutan pesan antara objek sistem. Perbedaan antara collaboration dan sequence diagram adalah collaboration diagram memperlihatkan bagaimana hubungan antara beberapa objek, sedangkan sequence diagram memperlihatkan bagaimana urutan kejadian.

a. Collaboration Tampilkan Home

Collaboration tampilkan home mendeklarasikan alur kerja dan hubungan antar objek dalam melakukan aktifitas admin. Seperti tampak pada gambar berikut :

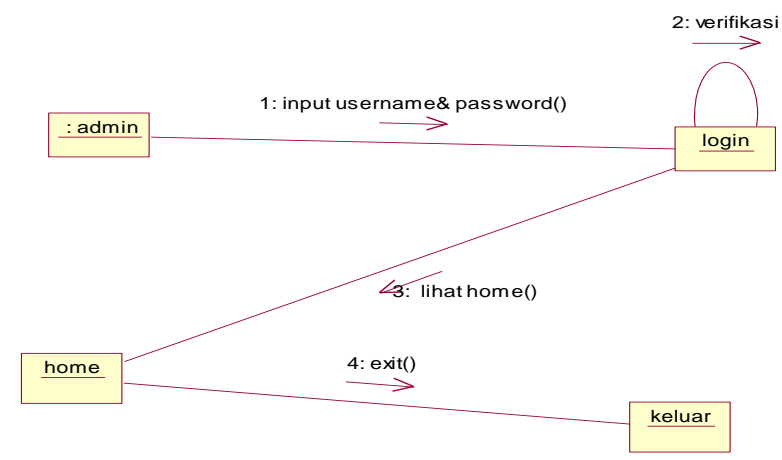

Gambar 7. Collaboration Login dan Submenu Beranda

b. Collaboration Kelola Data

Collaboration tampilkan kelola data mendeklarasikan alur kerja dan hubungan antar objek dalam melihat laporan produksi. Seperti tampak pada gambarberikut:

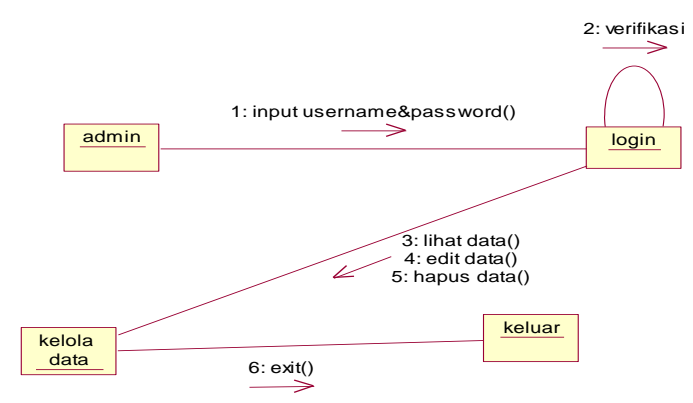

Gambar 8. Colaboration Diagram Tampilkan Laporan 


\section{c. Collaboration Tampilkan Prediksi Produksi}

Collaboration tampilkan prediksi produksi mendeklarasikan alur kerja dan hubungan antar objek dalam dalam melakukan aktifitas input perhitungan fuzzy dan menyimpan hasil prediksi produksi.

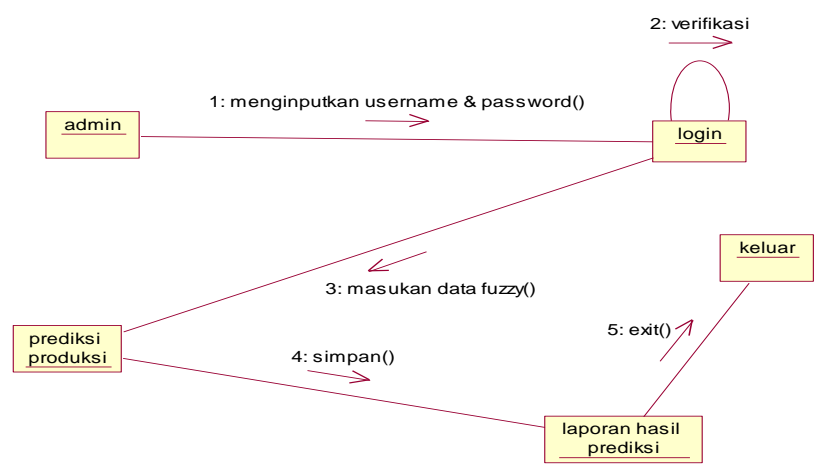

\section{Gambar 9. Colaboration Diagram Tampilkan Laporan}

\section{Activity Diagram}

Activity diagram menggambarkan proses-proses yang terjadi mulai aktivitas dimulai sampai aktivitas berhenti. Activity diagram ini mirip dengan flowchart diagram. Yang perlu diperhatikan disini adalah bahwa diagram aktivitas menggambarkan aktivitas sistem bukan apa yang dilakukan actor, jadi aktivitas yang dapat dilakukan oleh sistem.

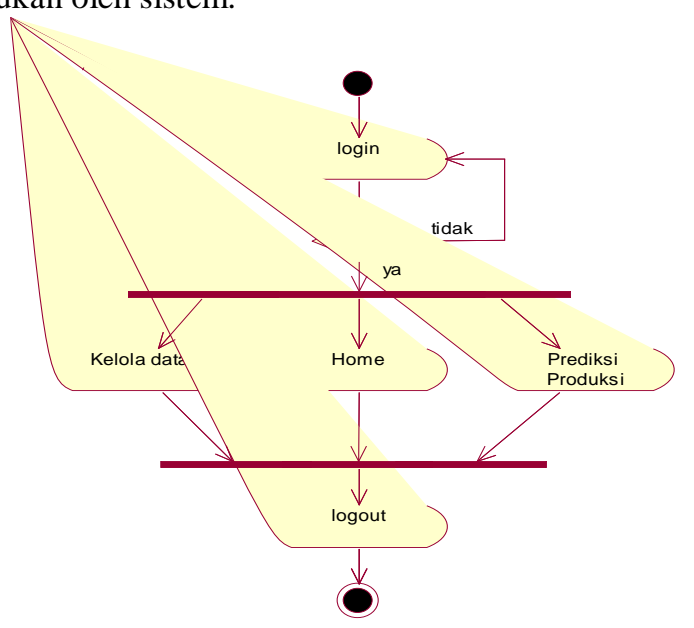

Gambar 10. Activity Diagram

\section{Statechart diagram}

Digunakan untuk menggambarkan perubahan status atau transisi status dari sebuah mesin atau sistem atau objek. Jika diagram sekuen digunakan untuk interaksi antar objek maka diagram status digunakan untuk interaksi di dalam sebuah objek. Perubahan tersebut digambarkan dalam suatu graf berarah. 


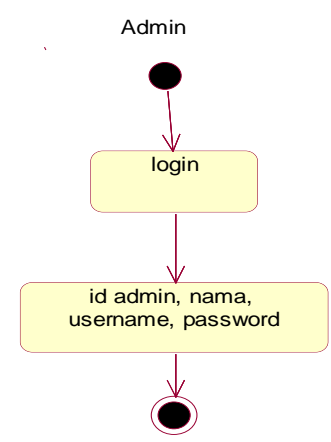

Gambar 11. State Chart Diagram Admin

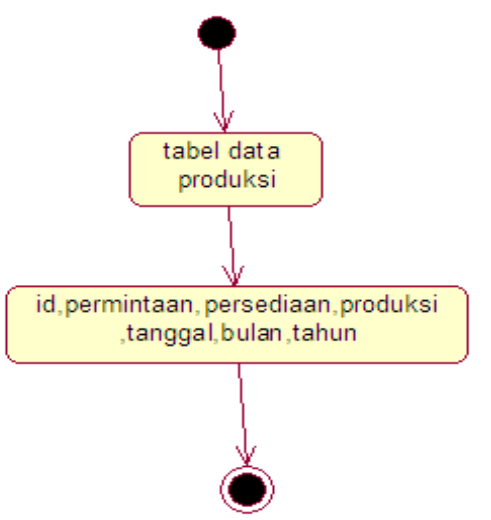

Gambar 12. State Chart Diagram Data Produksi

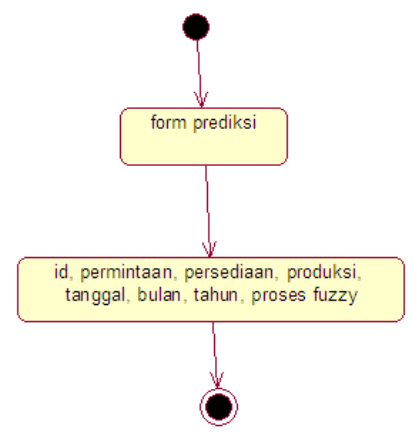

Gambar 13. State Chart Diagram Prediksi Produksi

\subsection{Deployment diagram}

Menunjukkan perangkat keras sistem dan perangkat lunak dalam perangkat keras tersebut. Diagram deployment berguna ketika solusi perangkat lunak dikerahkan di beberapa mesin dengan masingmasing memiliki konfigurasi yang unik. 


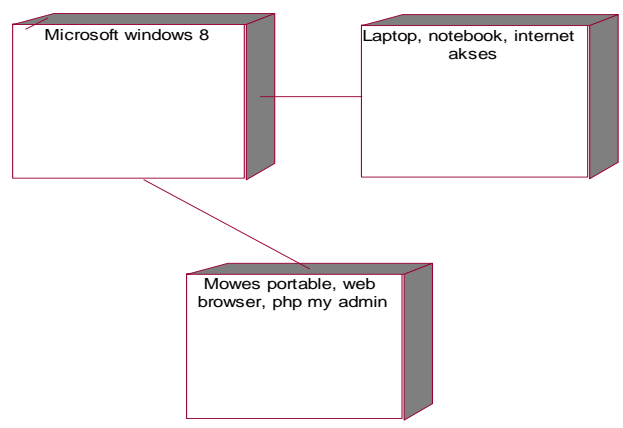

Gambar 14. Deployment Doagram

\section{Melakukan Implementasi Sistem}

Penerapan sistem yang akan dibangun, dalam pengimplementasiannya penulis menggunakan bahasa pemrograman PHP dan Database MySQL sebagai penyimpanannya.

Berikut ini adalah user interface dari program fuzzy logic tsukamoto Toko Rendang Asese Padang

\subsection{Desain Form Login}

Halaman login adalah halaman yang di rancang untuk memasukan username dan password dan mencocokan dengan data yang ada didalam database, tujuanya adalah agar admin bisa mengakses fungsifungsi yang terdapat didalam sistem.

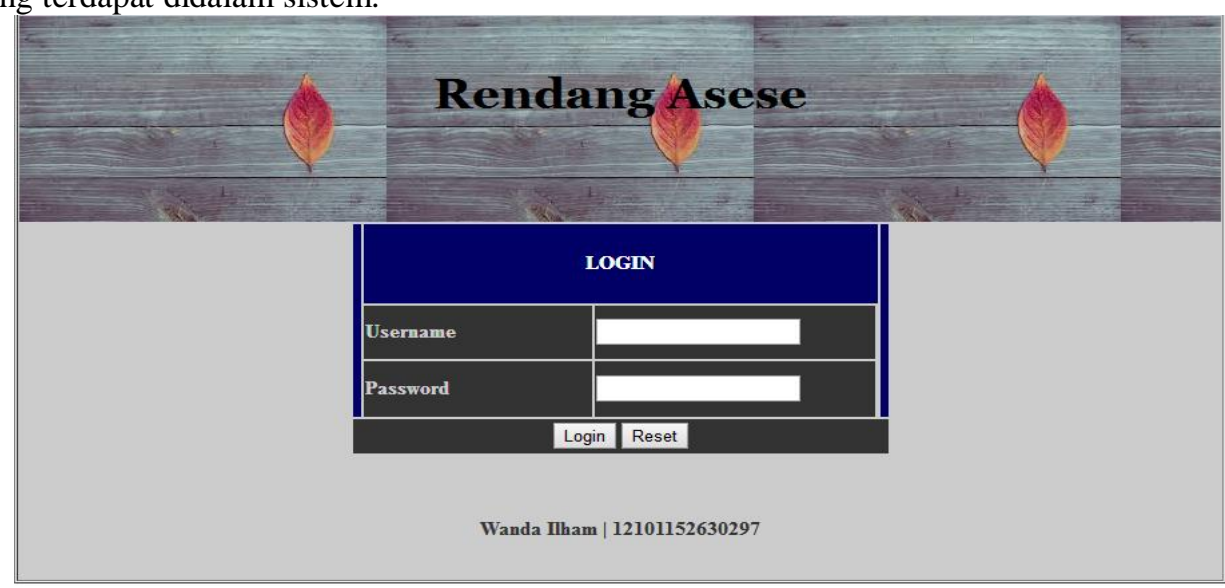

Gambar 15. Desain Halaman Login

\subsection{Desain Halaman Home}

Halaman home adalah halaman utama dari sistem, halaman ini akan ditampilkan jika username dan password yang dimasukan cocok dengan yang ada pada.database. 


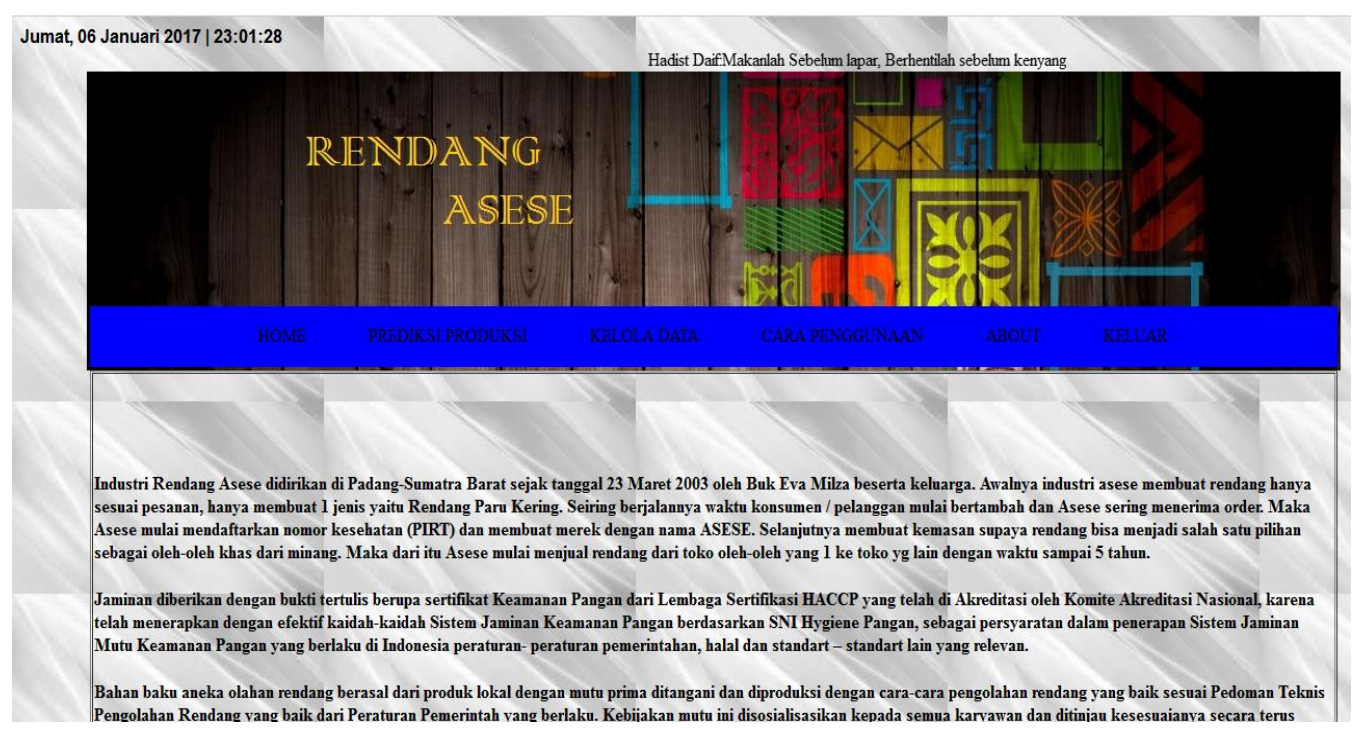

\section{Gambar 16. Desain Halaman Home}

4.3 Desain Halaman Prediksi Produksi

Pada halaman ini admin dapat melakukan proses prediksi produksi dengan cara memilih bulan yang akan digunakan sebagai variabel penentu jumlah produksi pada form priode, kemudian melakukan pemilihan bulan yang akan diprediksi jumlah produksinya dengan memasukan jumlah permintaan serta jumlah persediaan.

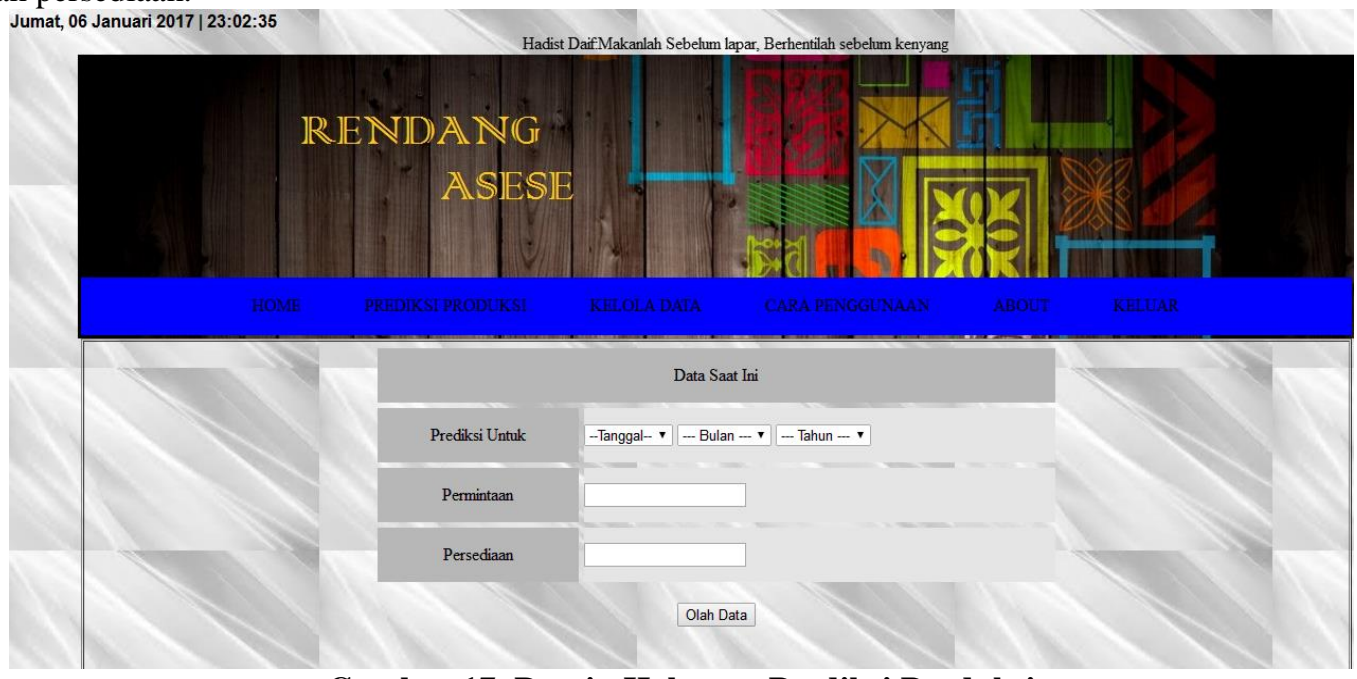

Gambar 17. Desain Halaman Prediksi Produksi

\subsection{Desain Halaman Hasil Prediksi}

Halaman ini menampilkan hasil prediksi jumlah produksi menggunakan metode tsukamoto berdasarkan data yang sudah dimasukan sebelumnya. 


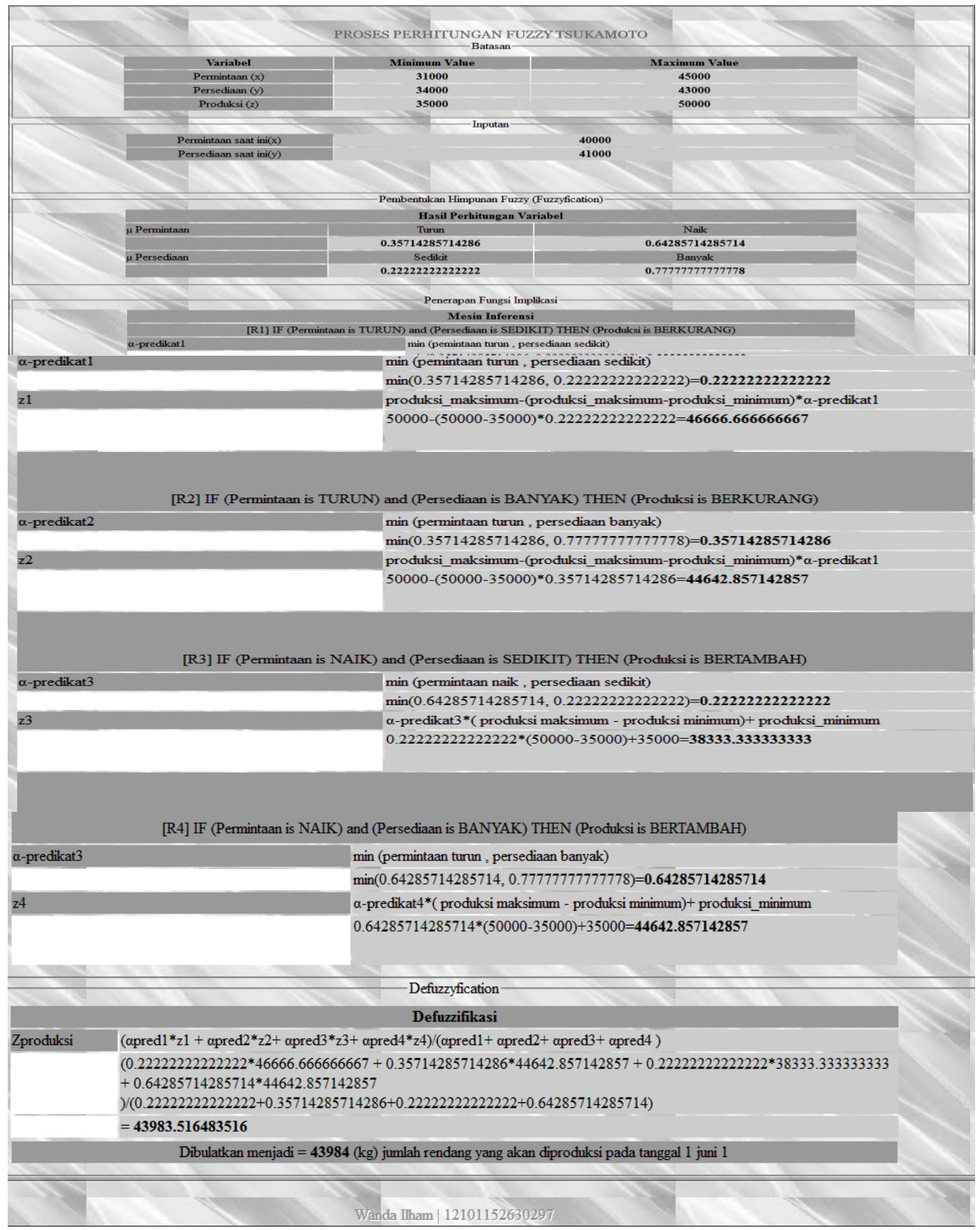

Gambar 18. Desain Halaman Laporan Hasil Prediksi

\section{Kesimpulan}

Setelah merancang Aplikasi Fuzzy Untuk Menentukan Jumlah Produksi Rendang Pada Usaha Rendang Asese Berbasis Web Menggunakan Metode Tsukamoto, penulis dapat menyimpulkan sebagai berikut : 
1. Dengan dibangunnya sistem ini, perusahaan Rendang Asese dapat menentukan hasil produksinya secara cepat dan efektif .

2. Dengan metode fuzzy logic ini dapat membantu pihak perusahaan Rendang Asese dalam penentuan hasil produksi rending mereka, tidak terjadi kekurangan rending atau kelebihan produksi rendang,

\section{Daftar Pustaka}

Journal:

[1] Jurnal Pelita Informatika Budi Darma, Volume : VII, Nomor: 2, Agustus 2014 Roger S. Pressman, "Software Engineering, A Beginner's Guide", McGraw Hill, 1998.Calero C, Piatiini M, Pascual C, Serrano MA. Towards Data Warehouse Quality Metrics. Proceedings of the 3rd Intl. Workshop on Design and Management of Data Warehouses (DMDW). Interlaken. 2009; 39: 2-11. (in this case, city: Interlaken, year: 2009, Vol.39, page: 2-11)

[2] Jurnal KomTekInfo Fakultas Ilmu Komputer, Volume 2, No.2, Des 2015.

[3] Jurnal Sistem Informasi (JSI), Volume 7, No.1, 1 April 2015

\section{Texbooks:}

If the references are refer to specific page range in a book

[1] A.S, Rosa \& Shalahuddin M. (2013). Modul Pembelajaran Rekayasa Perangkat Lunak (Terstruktur dan Berorientasi Objek). Bandung: Informatika..

[2] Kusumadewi, Sri, 2000, "Perancangan Sistem fuzzy : Studi Kasus Prediksi Jumlah Produksi dan Harga Jual Barang” dalam Jurnal Teknologi Industri Volume 5, No.1. Jogjakarta:Ward J, Peppard J. Strategic planning for Information Systems. Fourth Edition. West Susse: John Willey \& Sons Ltd. 2007: 102104.

[3] Kusumadewi, Sri. 2003. Artificial Intelligence (Teknik dan Aplikasinya). Yogyakarta: Graha Ilmu.

[4] Kusumadewi Sri. \& Hari Purnomo. (2004). Aplikasi Logika Fuzzy Untuk Sistem Pendukung Keputusan (Fuzzy Logic Applications for Decision Support Systems). Edisi Pertama (First Edition). Penerbit Graha Ilmu (Graha Sciences Publishers): Yogyakarta.

[5] Mandala, Eka Praja Wiyata. 2015. Web Programming ( Project 1 e.p.w.m Forum ).

[6] Peranginangin, Kasiman (2006). Aplikasi Web dengan PHP dan MySQL. Yogyakarta: Penerbit Andi.

[7] Suparman \& Marlan 2007, Komputer Masa Depan Pengenalan Artificial Intelligence, Andi Offset, Yogyakarta.

[8] Sutojo, T, Mulyanto, Edi dan Suharto, Vincent. (2011). Kecerdasan Buatan. Yogyakarta: Penerbit Andi. 